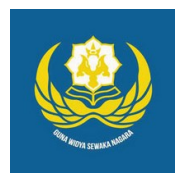

Jurnal Analogi Hukum

Journal Homepage: https://ejournal.warmadewa.ac.id/index.php/analogihukum

\title{
Pembebanan Hypotek Atas Kapal Laut dalam Perjanjian Kredit Bank
}

\author{
Dimas Hadi Prastya*, I Nyoman Putu Budiartha dan Desak Gd.Dwi Arini \\ Universitas Warmadewa, Denpasar-Bali, Indonesia \\ *hadiprastya@gmail.com
}

How To Cite:

Prastya, D, H., Budiartha, I, N., Arini, D, G, D. (2020). Pembebanan Hypotek Atas Kapal Laut dalam Perjanjian Kredit Bank. Jurnal Analogi Hukum, 2 (2). 155-159. Doi: https://doi.org/10.22225/ah.2.2.1894.155-159

\begin{abstract}
The Bank temporarily gives or disburses credit to usually preceded by an agreement that is usually called a draft loan agreement. In the loan agreement, there is a statement, as collateral when paying the credit, the agreement of the debtor is in default. In the banking practice specifically credit problems are known to have various institutions. While seen from the object there is a collateral institution of the owner of movable and inanimate objects. The formulation of the problem in this paper is 1) What are the conditions that must be met by the imposition of a mortgage on a ship in a bank credit agreement? and 2) What is the procedure for loading a mortgage on a ship in a bank credit agreement? This type of research used in this research is Empirical Legal Research that is taking facts that occur in the field, obtained through explanations from informants and can be understood by understanding the real law or in accordance with community life in society. The results of this study are, 1) Requirements that must be approved for the imposition of mortgages on marine vessels in a bank credit agreement, namely ships that have entered and are listed in the Indonesian ship list, the owner of the ship that receives a mortgage and who wants to accept individuals for ship assistance (made in in the presence of a Notary) 2) procedures for loading a mortgage on a ship in an approved bank credit agreement and the counter registrants of the ship list are approved for completeness of administration in less than 5 (five) days agreed upon when the documents are received as summarized. Ships that have entered the shipping list and other vessels in the process and parts of the ship that can be given mortgage rights. Like a ship that is burdened with a mortgage, the mortgage recipient is given a ship mortgage deed that has the same executorial power as the result of a trial that has permanent and easy legal power. Sanctions due to mortgage regulations for marine vessels are emphasized in order to prevent arbitrariness from the Office of the Harvesting Office and Port Authority in managing mortgage loading for ships.
\end{abstract}

Keywords: Credit, Hypotek, Ship.

Abstrak-Pihak Bank sesaat memberikan atau mnecairkan kredit terhadap biasanya didahului dengan perjanjian yang biasanya disebut draf perjanjian peminjaman. Di dalam perjanjian kredit dicantumkan anggunan, sebagai jaminan saat melunasi kredit apabila debitur melakukan wanprestasi. Didalam praktek perbankan khususnya masalah perkreditan dikenal adanya berbagai lembaga jaminan yang setiap mempunyai ciri-ciri yang berbeda. Sedangkan dilihat dari obyeknya ada lembaga agunan pemilik obyek barang bergerak dan benda mati. Adapun rumusan masalah dalam tulisan ini adalah 1) Syarat-syarat apa saja yang harus dipenuhi pembebanan hypotek atas kapal laut dalam perjanjian kredit bank? dan 2) Bagaimana tata cara pembebanan hypotek atas kapal laut dalam perjanjian kredit bank? Tipe penelitian yang di gunakan dalam penelitian ini yaitu Penelitian Hukum Empiris yaitu di ambil berdasarkan fakta yang terjadi di lapangan, yang didapatkan melalui penjelasan-penjelasan dari informan dan di pelajari dengan sikap hukum yang nyata atau sesuai dengan kehidupan hidup di masyarakat. Hasil dari penelitian ini yaitu,1) Syarat yang harus dipenuhi pembebanan hypotek atas kapal laut dalam perjanjian kredit bank, yaitu Kapal yang telah masuk dan tercap dalam list kapal Indonesia, empunya kapal serta yang menerima hipotek dan atau yang menjadi penerima secara perseorangan atas kuasa kapal (dibuat di hadapan Notaris) mengajukan permohonan kehadapan pemimpin pendaftar dan membuat perjanjian balik nama. 2) tata cara pembebanan hypotek atas kapal laut dalam perjanjian kredit bank pemegang yang terdaftar serta para pencatat balik daftar kapal meninjau kelengkapan administrasi dalam waktu kurang dari 5 (lima) hari terhitung saat dokumen permohonan sudah rangkum. Kapal yang telah masuk list perkapalanm serta kapal lain yang dalam proses dan bagian kapal yang

Jurnal Analogi Hukum, Volume 2, Nomor 2, 2020. CC-BY-SA 4.0 License 
demikian dapat diberikan hak tanggungan. Seperti bahwa kapal telah dibebani hipotek, maka penerima hipotek diberikan grosse akta hipotek kapal yang mempunyai kekuatan eksekutorial yang sama dengan hasil dari pengadilan yang memiliki kekuatan hokum yang tetap dan tepat.Pemerintah dinas perhubungan perlunya memperketat mengenai dokumen-dokumen mengenai legalitas kapal untuk pembebanan hipoteknya serta sanksi-sanksi akibat dari aturan hipotek untuk kapal laut lebih di tekankan guna mencegah tindakan kesewenang-wenangan dari pihak Kantor Kesyahbandaran dan Otoritas Pelabuhan dalam melakukan pengurusan pembebanan hipotek atas kapal laut.

Kata Kunci: Kredit, Hypotek, Kapal.

\section{Pendahuluan}

Dalam pelaksanaannya, saat melakukan pembangunann hendaknya selalu memperhatikan keseimbangan dan keharmonian, dengan memperhatikan segala jenis pembangnunan termasuk diantaranya dalam hal ekonomi dan keunaga. Untuk memberdayakan perekonomian rakyat, pemerintah harus senantiasa menciptakan perekonomian yang sehat, mantap dan berkesinambungan sehingga masyarakat dapat bergerak dan berusaha dengan baik sesuai dengan keahlian, ketrampilan dan kemampuan sendiri.

Bank pada saat memberikan fasilitas angunan terhadap seseorang biasanya didahului dengan perjanjian yang biasanya disebut draf perjanjian peminjaman. Dalam draf tersebut akan tercantum angunan atau jaminan, sebagai jaminan untuk melunasi kredit apabila debitur melakukan wanprestasi. Dengan bertitik tolak adanya jaminan pada perjanjian kredit bank, maka dapat dikatakan bahwa acara yang berlangsung dalam berbagai bidang yang berujung pada pemerluan fasilitas pinjaman dalam usahanya, memberikan ketentuan berupa angunan merupakan keamanan modal dan kepastian hukum bagi si pemberi modal, dengan memperhatikan pernyataan tersebut diatas dan dikaji lebih jauh betapa pentingnya lembaga jaminan yang dapat memberikan kepastian hukum guna pelunasan hutang atau kredit.

Didalam praktek perbankan khususnya masalah perkreditan dikenal adanya berbagai lembaga jaminan yang masing-masing mempunyai ciri-ciri yang berbeda apabila kita lihat dari bahan ada instansi yang memiliki bahan benda bergeral dan benda mati.

Suatu Bank dalam memberikan fasilitas kredit tidak selalu bisa lolos, dalam artian sebuah bank itu dalam memberikian kredit harus selalu berhati-hati. Karena sebuah bank tersebut dalam memberikan fasilitas kredit kepada masyarakat harus juga memperhatikan alasan pemberian kredit serta kesiapan masyarakat itu untuk membayar kreditnya karena hal itu yang menanggung resikonya adalah dari pihak bank. Pemberian kredit itu juga tergantung dengan prinsip-prinsip seperti kepercayaan serta jangka waktunya (Djumhana, 1997).

Kapal menurut sifatnya adalah suatu barang bergerak, tetapi kapal yang besarnya lebih dari 20 meter kubik menurut Undang-Undang dipersamakan dengan barang yang tidak bergerak dan dapat didaftarkan (Subekti, 1994). Kapal-kapal yang didaftarkan adalah kapalkapal yang disebutkan dalam pasal 314 Kitab Undang-Undang Hukum Dagang, yaitu kapalkapal yang ukuran bagian dalam dua puluh meter kubik bruto atau lebih, sehingga kapal-kapal yang ukuran kurang dari dua puluh meter kubik maka kapal tersebut tidak memerlukan pendaftaran.

Dengan mengambil tolak ukur pendaftaran, maka kapal yang didaftarkan adalah termasuk barang-barang yang tidak bergerak sehingga dapat dibebani hypotek dalam perjanjian kredit.

Dari uraian pada latar belakang masalah tersebut, maka dapat ditemukan dua rumusan masalah yang akan dibahas dalam penelitian ini, yaitu: 1) Syarat-syarat apa saja yang harus dipenuhi pembebanan hypotek atas kapal laut dalam perjanjian kredit bank? dan 2) Bagaimana tata cara pembebanan hypotek atas kapal laut dalam perjanjian kredit bank?

Tujuan penelitian dibagi menjadi dua yaitu tujuan yang sifatnya umum dan yang sifatnya khusus. Untuk tujuan umumnya yaitu: a) untuk dapat memenuhi syarat tugas terakhir yang ada pada Fakultas Hukum Universitas Warmadewa; b) untuk salah satu sarana dalam penerapan ilmu hukum yang didapat pada saat kuliah yang terjadi didalam masyarakat tentang prosedur mediasi perkara cerai talak; c) untuk sarana penyalur pemikiran yang bisa berguna untuk semua orang yang ada kaitannya dengan masalah yang diteliti.

Tujuan khususnya yaitu: 1) untuk mengetahui syarat-syarat apa saja yang harus dipenuhi pembebanan hypotek atas kapal laut dalam perjanjian kredit bank; dan 2) untuk mengetahui tata cara pembebanan hypotek atas kapal laut dalam perjanjian kredit bank.

\section{Metode}

metodologi dalam suatu penelitian merupa- 
kan cara menggambarkan sesuatu dengan menggunakan pikiran dengan jelas agar dapat menggapai suatu tujuan yang diinginkan, sedangkan penelitian merupakan suatu kegiataan untuk menemukan, merumuskan serta menganalisis sampai dengan menyusun laporan. Untuk menemukan penjelasan tentang segala sesuatu yang berkaitan dengan pokok permasalahan sehingga diperlukan suatu pedoman penelitian,

Menurut Ronny Soemitro bahwa, penelitian empiris yaitu penelitian hukum yang memperoleh datanya dari data primer atau data yang di peroleh langsung dari masyarakat (Soemitro, 1998). Tipe Penelitian, ini menggunakan pendekatan empiris, yaitu diambil dari fakta yang terjadi di lapangan, yang di dapatkan melalui penjelasan-penjelasan dari informan dan di pelajari dengan sikap hukum yang nyata atau sesuai dengan kenyataan hidup di masyarakat.

Pendekatan Konseptual, pendekatan ini berkembang dari pandangan-pandangan atau doktrin yang berkembang di dalam ilmu hukum. Pendekatan ini sangat penting sebab pemahaman terhadap pandangan atau doktrin yang berkembang dalam ilmu hukum dapat menjadi pijakan untuk membangun argumentasi hukum ketika menyelesaikan isu hukum yang di hadapi. Pendekatan Perundang-Undangan, pendekatan yang di lakukan dengan menelaah semua peraturan perundang-undangan dan regulasi yang bersangkut paut dengan isu hukum yang di tangani, dalam pendekatan perundangundangan perlu memahami hirarki, dan asasasas dalam peraturan perundang-undangan.

Sumber data yang digunakan yaitu data primer, merupakan data yang mengikuti dimana data itu di peroleh langsung dari lapangan yang di jadikan obyek atau lokasi penelitian yaitu di Kantor Kesyahbandaran dan Otoritas Pelabuhan Kelas II Bali. Adapun data primer yang di peroleh yaitu dari Kepala Kantor beserta staf pelaksanaan di Kantor Kesyahbandaran dan Otoritas Pelabuhan Kelas II Bali

\section{Hasil Penelitian Dan Pembahasan}

\section{Syarat-Syarat Dipenuhinya Pembebanan Hy- potek Atas Kapal Laut Dalam Perjanjian Kredit Bank}

Kata hypotek merupakan berasal dari bahasa romawi yaitu hypotheca, dalam bahasa belanda terjemahannya adalah under setting, dalam Bahasa Indonesia adalah pembebanan (Badrulzaman, 1980). Satu kreditur yang mempunyai kedudukan istimewa merupakan kreditur yang memegang hipotik.

Vollmar menyebutkan bahwa hipotik merupakan suatu hak kebendaan atas benda yang tidak bergerak dimaksud agar bisa memberi orang yang mempunyai hak (pemegang hipotik) sesuatu kenikmatan dari sebuah benda, tetapi yang dimaksud yaitu hanya memberi jaminan untuk melunasi suatu hutang dengan di lebih diutamakan (Vollmar, 1989).

Seperti yang dijelaskan dalam bukunya Hartono Hadisoeprapto yaitu dijelaskan, bahwa hipotik itu merupakan wujud dari jaminan kredit yang ada akibat dari suatu perjanjian, yakni sebuah wujud dari jaminan yang apa adanya harus diperjanjikan lebih dulu (Hadisoeprapto, 1984).

Dalam suatu perjanjian pembebanan hipotik harus ada dua pihak yang terikat yaitu pihak yang memberikan hipotik dan pihak yang diberikan hipotik. Yang memberikan hipotik yakni suatu pihak yang dijadikan sebagai jaminan pemberian suatu ha katas benda (hipotik), yang atas benda tersebut tidak bergerak, umumnya suatu pihak yang mengadakan suatu hutang yang terikat dengan hipotik, akan tetapi hipotik dibebankan kepada pihak ketiga (Salim, 2011).

Hanya orang yang berwenang memindahtangankan saja dyang berhak memberikan atau meletakan pembebanan hipotik tersebut. Belum diatur secara jelas mengenai siapa yang dapat memberikan pembebanan hipotek dan siapa yang dapat menerima hak atas pembebanan tersebut. Asas dalam Hypotik tidak bida di pecah-pecah, artinya bahwa hipotik tersebut membuat pembebanan pada seluruh obyek/ benda yang telah diberikan hipotik yang keseluruhan atau tidak merupakan bagian dari benda bergerak. Meskipun telah dibayar setengah atau beberapa bagian dari kesulurhan jumlah hutang maka tetap tidak mengurangi atau menghilangkan sebagai dari benda yang telah ditanggu oleh janji tersebut. Janji (Bedingen) dalam Hipotik yaitu sebagai berikut:

Suatu perkaitan atau pasangan dan atau kami sebut pembebanan kapal lait dengan pemberian hak tanggungan ialah hubungan hukum sekaligus pelanggaran hukum yang kemudian akan menciptakan bermacam hukuman pagi semua pihak. Interaksi hukum sewaktu-waktu membawa dampak yang menimbuklakn hak serta kewajiban bagi semua pihak yang melakukan tindakan hukum seperti pembebanan hak tanggungan kapal dalam draf perjanjian. 
Salah seorang yang melakukan suatu perjanjian yang tertulis ialah yang bersepakat atau setuju dengan tertulis terhadap satu sama lain dan kemufakatan ini adalah saat berlakunya suatu kerjasama yang dimaksud, yang memerlukan pihak lainnnya sebagai pihak yang dtentukan menjadi bagian yang memeiliki kewenangan dalam membuat perjanjian tertulis itu.

Adanya sijil otentik dan sijil di bawah tangan, bahwa sijil bawah tangan ialah sijil yang telah dibikin oleh semua pihak tanpa terkeculai melibatkan pemimpin yang sangat berkuasa membuat sijil sperti Notaris, PPAT atau pejabat yang lain. Berlainan dengan sijil dibawah tangan yang sama sekali tidak terlibah daroi campur tangan pihak yang mempunyai hal dalam membuta sijil. Susunan Pemimpin Pendaftar dan Para Pencayatat Balik Nama Kapal adalah sebagun dengan susunan Pemimpin Para Pembuat Sijil Tanah atau yang kami septum PPAT, yang kepadannanya ialah dalam inventarisasi, sedangkan dalam perbedaanya ialah hal yang di daftarkan oleh Pembuat Sijil ialah tanah dan ha katas apa yang dimiliki dalam hal ini ialah Tanah., sedangkan apa yang didaftarkan atau diinventariskan oleh pemimpin pendaftar adalah kapal itu sendiri. Para Bagian yang berwenang sesuai diberikan aturan aturan tersendiri.

Ketetapan ini, pengalihan hak tangungan adalah tindakan hukum yang sering ada antara pemeri hipotik dan penerima hak hipotik kapal, dan merupakan tindakan hukum kesepkatan yang ada di dalamnya dengan kaitan sejumlah hak dan kewajiban dengan berupa timbal balik. Tanggungan Hipotek sebgai jaminnan yang memebrikan pinjaman bank diutamakan dengan munculnya kesepkatan diantara semua pihak, yang di dalamnya berisi bebebrapa hak dan kewajiaban bagi semuanya. Kelayakan dan kemestian yang bersifat timbal balik yang kemudian akan menjadikan hal penting dalam kesepatan peminjaman yang dibebani dengan hak tanggungan kala laut. Pemuasan kelayakan yang telah dijanjikan secara bersama sama adalah hal penting dalam pelaksanan perjanjian kesepakatan yang dapat saja kepada salah satunya pihak terkait tidak melakukan kelayakan yang sesuai sebagai mana mestinya.

Dikarenakan hukum terjadi oleh karenanya akan timbul konflik dalam kesepakatan kerjasama pinjaman yang akan dibebankan kepada Hipetak Kapal Laut, yang sering dating dari pihak pemilik dan atau yang diberikan hak tanggungan yakni intansi perbankan yang dapat kemudian di gugat secara hukum dalam hal pemenuhan gugatan yang terjadi karena intansi tersbut pailit atau merugi dikarenakan oleh ketidak tepatan melakukan payment utang beserta bunga yang sudah disepakati.

\section{Tata Cara Pembebanan Hypotek Atas Kapal Laut Dalam Perjanjian Kredit Bank}

Bagi seorang kreditur pemegang hipotik yang sudah didaftarkan bisa menuntut hak mereka atas suatu benda yang tidak bergerak, agar diberikan posisi pada tingkat dan agar dibayarkan menurut nomor urut pendaftaran. (Henny Tanuwidjaja, 2012: 87) setelah debitur diperingatkan oleh kreditur maka kreditur mempunyi hak untuk menyita barang-barang yang sudah terikat pada tangan dari pihak ketiga yang telah memegang kuasa atas barang tetap tersebut dan bisa memasarkan untuk penjualan barag tersebut. Hanya orang yang berwenang memindahtangankan saja dyang berhak memberikan atau meletakan pembebanan hipotik tersebut.

Kapal jika dilihat berdasarkan sifatnya merupakan suatu benda yang bergerak, tapi kapal yang besarnya melebih dari 20 meter kubik menurut Undang-Undang dipersamakan dengan barang yang tidak bergerak dan dapat didaftarkan.

Didalam praktek perbankan khususnya masalah perkreditan dikenal adanya berbagai lembaga jaminan yang masing-masing mempunyai ciri-ciri yang berbeda.apabila kita lihat dari bahan ada instansi yang memiliki bahan benda bergeral dan benda mati.

Belum ada aturan yang jelas mengenai siapa yang dapat memberikan pembebanan hipotek dan siapa yang dapat menerima hak atas pembebanan tersebut. Asas dalam Hypotik tidak bida di pecah-pecah, artinya bahwa hipotik tersebut membuat pembebanan pada seluruh obyek/ benda yang telah diberikan hipotik yang keseluruhan atau tidak merupakan bagian dari benda bergerak. pembebanan hipotik harus ada dua pihak yang terikat yaitu pihak yang memberikan hipotik dan pihak yang diberikan hipotik. Yang memberikan hipotik yakni suatu pihak yang dijadikan sebagai jaminan pemberian suatu ha katas benda (hipotik), yang atas benda tersebut tidak bergerak, umumnya suatu pihak yang mengadakan suatu hutang yang terikat dengan hipotik, akan tetapi hipotik dibebankan kepada pihak ketiga dalam kasus-kasus pembebanan hipotek yang harus melibatkan 3 pihak selalu ada permasalahan yang timbul yaitu mengenai jangka waktu pengem- 
baliannya ataupun tindakan-tindakan wanprestasi yang dilakukan oleh salah satu pihak

Perbuatan ingkar janji atau wanprestasi tidak dapat dipisahkan dari adanya suatu perjanjian yang pada akhirnya semua itu harus ditanggung oleh pihak kreditur, karena pihak kreditur berhak nuntut ganti rugi serta melakukan pelelangan terhadap suatu jaminan kebendaan apabila terjadinya wanprestasi.

\section{Simpulan}

Dari penjelasan pendahuluan sampai dengan hasil penelitian dan pembahasan, maka dapat disimpulkan yaitu : 1) Mengenai Syaratsyarat pembebanan hipotik kapal laut yaitu Kapal-kapal Indonesia yang ukurannya paling sedikit dua puluh meter kubik isi kotor dapat didaftarkan di suatu daftar kapal sesuai dengan peraturan-peraturan yang akan diberikan dengan kordonasi tersendiri. Atas kapal-kapal yang terdaftar dalam daftar kapal, kapal-kapal yang sedang dibuat dan bagian-bagian dalam kapal-kapal yang demikian itu, dapat diadakan hipotik. Pembebanan hipotik yang pada intinya terdapat suatu perjnjian atau kesepakatan. Permasalahan hukum yang akan timbul kedepannya yaitu perbuatan wanprestasi dari pihak kreditur yang dibebani hipotik,yang pasti perbuatan itu datangnya dari pemilik atau yang memegang hipotik yaitu lembaga perbankan maka bisa dilakukan penyelesaian masalahnya dengan mengajukan gugatan hukum sebagai pemenuhan tuntutan hukum karena lembaga perbankan tersebut mengalami kerugian atas keterlambatan atau ketidakmampuan pembayaran hutang serta bunga yang telah disepakati.

2) Mengenai Tata cara pembebanan hypotek atas kapal laut ada beberapa tahap yang harus dilewati terlebih dahulu, yaitu, Tahap Permohonan Pemberian Fasilitas Kredit, Tahap Penelitian Dokumen, Tahap Persetujuan Pemberian Fasilitas Kredit, Tahap Penandatanganan Perjanjian Kredit dan Perjanjian Pengikatan Jaminan dan Tahap Pembebanan Hipotek Atas Kapal. Setelah kelengkapan persyaratan pembebanan hipotek atas kapal telah terpenuhi, maka dibuatlah akta hipotek kapal dengan dilampiri grosse akta kapal asli. Tata cara pembebanan hypotek atas kapal laut dapat dilakukan dengan Pemilik kapal dan penerima hipotek atau penerima hipotek secara sendiri atas kuasa pemilik kapal mengajukan permohonan kepada Pejabat Pendaftar dan Pencatat Balik nama Kapal di tempat kapal didaftar.

\section{Daftar Pustaka}

Badrulzaman, M. darul. (1980). Bab-bab Tentang Hypotek. Bandung: alumni Bandung.

Djumhana, M. (1997). Hukum Perbankan Indonesia. Bandung: Citra Aditya Bakti.

Hadisoeprapto, H. (1984). Pokok-Pokok Hukum Perikatan dan Hukum Jaminan. Yogyakarta: Liberty.

Salim, H. (2011). Perkembangan Hukum Jaminan di Indonesia. Jakarta: Rajawali Press.

Soemitro, R. H. (1998). Metodologi Penelitian Hukum dan Jurumetri. Jakarta: Ghalia Indonesia.

Subekti. (1994). Pokok-Pokok hukum Perdata. Jakarta: Intermasa.

Vollmar, H. F. A. (1989). Pengantar Studi Hukum Perdata. Jakarta: Rajawali Press. 